\title{
Tocolysis in farm animal reproduction
}

\author{
D.B. Bhoi
}

Livestock Research Station, Navsari Agricultural University, Navsari - 396450, Gujarat, India

E-mail: drdhirenvet@gmail.comMob: 0919925253536

Journal of Livestock Science (ISSN online 2277-6214) 13: 41-47

Received on 16/7/21; Accepted on 23/12/21; Published on 10/1/22

doi. 10.33259/JLivestSci.2022.41-47

\begin{abstract}
Tocolysis is an obstetrical procedure carried out with the use of medicines for delaying the parturition presenting preterm contractions. Various tocolytics have been studied with the objective of stopping preterm labor, increasing gestational age at parturition and preventing complications related to preterm birth. Preterm parturition accounts for about $70 \%$ of neonatal calf deaths. Commonly used tocolytic medications include $\beta_{2}$ agonists, calcium channel blockers, NSAIDs, oxytocin and prostaglandin antagonistic and magnesium sulfate. These can assist in delaying preterm delivery by suppressing uterine muscle contractions and their use is intended to reduce fetal morbidity and mortality associated with preterm birth. The tocolytic medicated animal must be kept under intensive observation because of its adverse effects on cardiovascular system and other complications. The suppression of contractions is often only partial and tocolytics can only be relied to delay birth for a few days. Further research and professional guidelines are needed on optimal use of these agents. This review aims to summarize the major classes of tocolytics, their effects and review the evidence regarding use of each.
\end{abstract}

Keywords: farm animal; labor; reproduction; parturition; tocolytics 


\section{Introduction}

Tocolysis, a Greek derivative (tokos $=$ childbirth or labor; lysis $=$ dissolution), refers to reduced myometrial contractions following administration of variety of agents designated astocolytic drugs (Norwitz et al., 1999). Chemically, these drugs are categorized to $\beta$-sympathomimetics, calcium antagonistics, oxytocin antagonistics, and prostaglandin antagonistics which are popular in human obstetrics in comparison to veterinary practice, where the use is restricted to only $\beta$-sympathomimetics like isoxsuprine, ritodrine, terbutaline and clenbuterol (Menard, 1994 and Garg et al., 2004).

The mode of administration is easy and desired action is exerted through activation of adenylecyclase followed by increased cAMP, protein phosphorylation and intracellular calcium sequesterization leading to diminished activity of contractile proteins culminating to muscle relaxation. These drugs act on $\beta$-receptors: $\beta-1$ and $\beta-2$ (Innes and Nicherson, 1975) in general, thus, might have side effects of cardiovascular origin besides maternal haemodynamics and fetal asphyxia (Matsuda et al., 2002).

Smooth muscles are innervated by the sympathetic nervous system having $\alpha$ and $\beta$ receptors; $\alpha$ receptors are responsible for the muscular contractions whereas $\beta$ receptors are responsible for the muscular relaxation. $\beta 1$ receptors are confined to heart and small intestine and $\beta 2$ receptors are confined to the vascular smooth muscle, myometrium, bronchial tree (Putnam et al.,1985). Stimulation of $\beta 2$ receptor causes bronchodilation, relaxation of the uterus and vasodilation in most species. So, drugs that produce this effect are termed uterine myorelaxants, tocolytic drugs or simply tocolytics.

Isoxsuprine lactate was used first in cattle (Ahlers and Anderson, 1967) with an introduction of other drugs, the detailed pharmacokinetics ofClenbuterol and Terbutaline has been studied in cattle (Dave et al., 1998 and Melanie et al., 2007). However, clinical applicationsespecially obstetrical problems including Preterm labor (Perez et al., 1997), nocturnal delivery (Hirst et al., 2005), dystocia (Erkert andMacallister, 2002), caesarean section (DeNooij, 1984), fetotomy (Menard and Diaz, 1987) and uterine prolapse (Zennetti, 1983) have been managed successfully apart from increased rate of pregnancies in recipients following surgical embryo transfer (Gregory and Rodrigues, 1986).

Experimental studies conducted in sheep with KUR-1246, new derivative of $\beta$-sympathomimetic group (Kiguchi et al., 2002) and Meluadrine Tartrate; a plant extract (Matsuda et al., 2002) in goats have shown many fold greater potency of these products as smooth muscle relaxants with less side effects on cardiovascular system, general metabolism of dam and fetus. Effect of Oxytocin on uterine involution, cervical dilation and resumption of ovarian activity post-lambing in ewes and other farm animals is well known (Mohamed et al 2021) hence axytocin antagonists are used as tocolytics.

\section{Drugs used as Tocolytics}

$\beta$-sympathomimetics - Isoxsuprine, Ritodrine, Terbutaline, salbutamol, Orciprenaline, Fenoterol,Clenbuterol, Meluadrine Tartrate, KUR-1246.

Calcium antagonists- Nifedipine, Verapamil, Nicardipine, Nitrendipine.

Oxytocin antagonists - Atosiban and all Beta-sympathomimetics.

Prostaglandin antagonists - Indomethacin

Other agents -glyceryltrinitrate, Extracts of Bryophyllumpinnatum, omega-3 long chain Polyunsaturates, NSAIDs and Magnesium sulfate (Norwitz et al, 1999).

Isoxsuprine lactate was the first agents to be used for treatment of preterm labor. Subsequently new agents invented that stimulate $\beta 2$ receptors andused as tocolytics without side effects, for examples-ritodrine, salbutamol, terbutaline, clenbuterol, orciprenaline (Garg et al, 2004).

Table 1. Commercially available tocolytic drugs

\begin{tabular}{|l|l|l|l|}
\hline S.N. & \multicolumn{1}{|c|}{ Proprietary name } & \multicolumn{1}{|c|}{ Ingredient } & Pharmaceutical Company \\
\hline 1 & $\begin{array}{l}\text { A.Duphaspasmin } \\
\text { B. Duvadilan }\end{array}$ & Isoxsuprine lactate & $\begin{array}{l}\text { Philips-Duphar (Holland) } \\
\text { DupharInterfran, Bombay (India) }\end{array}$ \\
\hline 2 & Yutopar & Ritodrine chloride & Philips-Duphar (UK) \\
\hline 3 & Brethine & Terbutaline Sulfate & Novartis Pharmaceuticals (USA) \\
\hline 4 & Ventolin & Salbutamolhemisulfate & Allen \&Hanbury'sPharma.(Canada) \\
\hline 5 & Alupent & Orciprenaline sulfate & Boehringer-lngelheim (Canada) \\
\hline 6 & Berotec & Fenoterolbromide & Boehringer-lngelheim(Canada) \\
\hline 7 & Ventipulmin, Planipart & Clenbuterolhydrochloride & Boehringer-lngelheim(Canada, Germany) \\
\hline
\end{tabular}

\section{Clinical use of tocolytic drugs}

Preterm labor/ threatened abortion

In spite of a tremendous efforts the incidence of premature labor in animals is around 5-7\% worldwide. Statistics indicate that preterm birth is the leading factorcausing neonatal morbidity and mortality in animals. In the routine practice progesterone therapy is generally advocated for the treatmentof premature labor, but it has some adverse effects like when labor pain has reached to its maximum amplitudes, the drug does not work or become ineffective. And the another side effect is, It prolongs gestation length, when administered during advanced stages 
of pregnancy, as a result, chances of dystocia increases due to additional weight gain of the fetus.

In a clinical trial when $300 \mu \mathrm{g}$, Clenbuterol, $\mathrm{i} / \mathrm{m}$, injected in a cow for the treatment of premature labor, the treatment induced inhibition of uterine contractions without any side effects. Kiguchi et al (2002) found that a newly synthesized B-sympathomimetic agent KUR-1246 is a very potent tocolyticagent. The tocolytic effects of KUR-1246 was compared with Ritodrine hydrochloride on oxytocin-induced uterine contraction in pregnant sheep and the efficacy was judged on the basis of cardiovascular parameters of dam and general metabolism of dam and fetus.They reported the potent effect of KUR-1246 (Table2).

In an experimental trial Matsuda et al (2002) found that a plant extract of Meluadrine tartrate has got a very good tocolytic property without any cardiovascular side effect on the dam when compared with a Bsympathetic agent Ritodrine hydrochloride in pregnant goats. They have compared the systolic, diastolic and mean blood pressure on the pregnant goats at 30,60, 90 and 120 minutes. Meluadrine tartrate was injected in goats at different dose level i.e. $0.03,0.1,0.3,1 \mu \mathrm{g} / \mathrm{kg} / \mathrm{min}$. and Ritodrine hydrochloride was injected at a dose of $1,3,10$, $30 \mu \mathrm{g} / \mathrm{kg} / \mathrm{min}$ (Table 3).

In a different study Perez et al (1997) carried out an experiment on non-pregnant adult goats and compared the tocolytic effect of Clenbuterol and Nifedipine on xylazine-induced alterations in the frequency of uterine contractions, 5 min- 1 in adult goats. They found that both the drugs caused a remarkable reduction in the uterine contractions induced by the administration of Xylazine (Table.4).

Table2. Comparative efficacy of Ritodrine and KUR-1246

\begin{tabular}{|c|c|c|c|}
\hline \multicolumn{2}{|c|}{$\begin{array}{c}\text { Ritodrine hydrochloride } \\
\text { (Oxytocin dose } 0.77-0.94 \mathrm{U} / \mathrm{kg} / \mathrm{min} \text { ) }\end{array}$} & \multicolumn{2}{|c|}{$\begin{array}{c}\text { KUR-1246 } \\
\text { (Oxytocin dose } 1.00 \mathrm{mU} / \mathrm{kg} / \mathrm{min} \text { ) }\end{array}$} \\
\hline Dose $(\mu \mathrm{g} / \mathrm{kg} / \mathrm{min})$ & $\begin{array}{l}\text { Uterine relaxation } \\
\text { rate }(\%)\end{array}$ & $\begin{array}{c}\text { Dose } \\
(\mu \mathrm{g} / \mathrm{kg} / \mathrm{min})\end{array}$ & $\begin{array}{l}\text { Uterine relaxation } \\
\text { rate }(\%)\end{array}$ \\
\hline 0.1 & -14.3 & 0.001 & 31.1 \\
\hline 0.3 & 14.9 & 0.003 & 63.1 \\
\hline 1.0 & 35.3 & 0.010 & 69.6 \\
\hline 3.0 & 68.8 & 0.030 & 91.3 \\
\hline 10.0 & 75.5 & 0.100 & 105.9 \\
\hline 30.0 & 79.4 & 0.300 & 96.3 \\
\hline \multicolumn{2}{|c|}{$\begin{array}{l}50 \% \text { inhibition dose } \\
(\mu \mathrm{g} / \mathrm{kg} / \mathrm{min}): 1.5\end{array}$} & \multicolumn{2}{|c|}{$\begin{array}{l}50 \% \text { inhibition dose } \\
(\mu \mathrm{g} / \mathrm{kg} / \mathrm{min}): 0.0024\end{array}$} \\
\hline
\end{tabular}

Table 3. Effect of meluadrine tartrate and ritodrine hydrochloride on goats

\begin{tabular}{|c|c|c|c|c|c|c|}
\hline & Control & Oxytocin & $30 \mathrm{~min}$ & $60 \mathrm{~min}$ & $90 \mathrm{~min}$ & $120 \mathrm{~min}$ \\
\hline \multicolumn{7}{|c|}{ Meluadrine tartrate treated goats $(0.03,0.1,0.3,1 \mu \mathrm{g} / \mathrm{kg} / \mathrm{min})$} \\
\hline Systolic (mmHg) & $114 \pm 10$ & $116 \pm 11$ & $115 \pm 11$ & $119 \pm 11$ & $115 \pm 11$ & $111 \pm 10$ \\
\hline Diastolic (mmHg) & $69 \pm 7$ & $72 \pm 7$ & $67 \pm 6$ & $67 \pm 4$ & $62 \pm 4$ & $60 \pm 5$ \\
\hline Mean (mmHg) & $84 \pm 8$ & $87 \pm 8$ & $83 \pm 7$ & $84 \pm 6$ & $80 \pm 6$ & $77 \pm 6$ \\
\hline Ritodrine hydrochloride treated goats $(1,3,10,30 \mu \mathrm{g} / \mathrm{kg} / \mathrm{min})$ \\
\hline Systolic (mmHg) & $120 \pm 8$ & $120 \pm 8$ & $115 \pm 8$ & $118 \pm 10$ & $118 \pm 11$ & $116 \pm 9$ \\
\hline Diastolic (mmHg) & $72 \pm 5$ & $73 \pm 4$ & $67 \pm 6$ & $66 \pm 5$ & $61 \pm 7$ & $60 \pm 6$ \\
\hline Mean (mmHg) & $88 \pm 6$ & $89 \pm 4$ & $83 \pm 6$ & $83 \pm 6$ & $80 \pm 7$ & $78 \pm 7$ \\
\hline
\end{tabular}

Table 4. Effect of various tocolytic drugs on uterine contractions in goats

\begin{tabular}{|l|c|c|c|c|}
\hline \multicolumn{1}{|c|}{ Group } & Basal & $5 \mathrm{~min}$ & $15 \mathrm{~min}$ & $30 \mathrm{~min}$ \\
\hline Xylazine, $(0.1 \mathrm{mg} / \mathrm{kg}, \mathrm{i} / \mathrm{v})$ & $7.6 \pm 1.6$ & $25.8 \pm 2.0$ & $17.2 \pm 2.0$ & $14.8 \pm 2.0$ \\
\hline Xylazine, $(0.1 \mathrm{mg} / \mathrm{kg})+$, Clenbuterol $(4 \mu \mathrm{g} / \mathrm{kg}) \mathrm{i} / \mathrm{v}$ & $7.4 \pm 1.7$ & $4.2 \pm 1.5$ & $8.4 \pm 2.1$ & $7.4 \pm 1.4$ \\
\hline Xylazine, $(0.1 \mathrm{mg} / \mathrm{kg})+$, Nifedipine $(80 \mu \mathrm{g} / \mathrm{kg}) \mathrm{i} / \mathrm{v}$ & $7.6 \pm 1.7$ & $2.2 \pm 1.6$ & $7.8 \pm 1.1$ & $7.0 \pm 1.2$ \\
\hline
\end{tabular}

\section{Controlled calving / nocturnal delivery}

In a routine clinical practice a controlled calving during nocturnal delivery can be achieved by mainly two ways. One is by using the PGF2 $\alpha$ and another is by using tocolytic drugs. When PGF2 $\alpha$ is used for this purpose, there will be a more incidence of retained placenta, whereas prediction of calving time is mandatory for using tocolytic drugs. Prediction of a calving time can be done by looking to the external physical signs and recording a body temperature of the animal prone to calve in a next few hours. The physical signs to be undertaken include lackening of sacrosciatic ligament, relaxation of perineum and vulva, distension of udder, vaginal mucous discharge. But these are difficult to quantify and their development in relation to calving varied considerably. Same way the body temperature is too variable to be used in prediction of parturition time (either side of $38.9{ }^{\circ}$ C).Looking to these entire phenomenona very accurate method for prediction of a calving time should be kept in mind.

Melanie et al., (2007) used Terbutaline, $5 \mathrm{mg} / \mathrm{kg}, \mathrm{i} / \mathrm{m}$, and proved it as a potential tocolytic drug to delay parturition and for various bovine obstetrical maneuvers. Certain factors affects the rate of tocolysis i.e. stage of labor, parity of animal, cervical dilatation \& fetal position and pelvic area of dam (Putnam et al., 1985). 
Clenbuterol Hydrochloride, $300 \mu \mathrm{g} \mathrm{i} / \mathrm{v}$ was used to postpone parturition in cows and found results as shown in table 5.

Putnam et al (1985) used Clenbuterol $300 \mu \mathrm{g}$, i/m, in heifers for postponement of parturition and found the variation in the length (minutes) of stage-I of parturition in heifers with large and small pelvic areas (table. 7).

Table 5. Effect of Clenbuterol hydrochloride to postpone parturition in cows

\begin{tabular}{|c|c|c|c|c|c|c|}
\hline \multirow[t]{2}{*}{$\begin{array}{l}\text { Animal } \\
\text { (No.) }\end{array}$} & \multicolumn{2}{|c|}{$\begin{array}{l}\text { Cervix } \\
\text { Degree of dilation at } \\
\text { treatment }(\mathrm{cm} .)\end{array}$} & \multirow[t]{2}{*}{$\begin{array}{l}\text { Minutes to } \\
\text { Tocolysis } \\
\text { (Minutes) }\end{array}$} & \multirow[t]{2}{*}{$\begin{array}{l}\text { Duration of } \\
\text { Tocolysis } \\
\text { (Hours) }\end{array}$} & \multirow{2}{*}{$\begin{array}{l}\text { Duration of } \\
\text { parturition after } \\
\text { resumption of } \\
\text { labor (Hours) }\end{array}$} & \multirow[t]{2}{*}{$\begin{array}{l}\text { Retension } \\
\text { of Placenta } \\
\text { (No.) }\end{array}$} \\
\hline & $2-4 \mathrm{~cm}$ & $4 \mathrm{~cm}$ & & & & \\
\hline \multirow{3}{*}{$\begin{array}{l}\text { Heifers } \\
(25)\end{array}$} & \multirow{3}{*}{19} & \multirow{3}{*}{6} & Mean 17.18 & Mean 4.9 & 0.74 & \multirow{3}{*}{2} \\
\hline & & & Min 10.00 & Min 3.5 & 0.5 & \\
\hline & & & Max 25.00 & Max 7.5 & 1.5 & \\
\hline \multirow{3}{*}{$\begin{array}{l}\text { Cows } \\
\text { (7) }\end{array}$} & \multirow{3}{*}{1} & \multirow{3}{*}{6} & Mean 21.44 & Mean 4.21 & 0.49 & \multirow{3}{*}{0} \\
\hline & & & Min 15.00 & Min 2.50 & 0.25 & \\
\hline & & & $\begin{array}{|ll|}\operatorname{Max} & 35.00 \\
\end{array}$ & \begin{tabular}{|ll} 
Max & 6.00 \\
\end{tabular} & 0.75 & \\
\hline
\end{tabular}

Table 6. Effect of Clenbuterol for postponement of parturition in heifers

\begin{tabular}{|c|c|c|}
\hline & Control & Clenbuterol \\
\hline Large Pelvic areas & \multicolumn{2}{|c|}{} \\
\hline Heifers (No.) & 10 & 13 \\
\hline Average & $119 \mathrm{~min}$ & $468 \mathrm{~min}$ \\
\hline Range & $30-230 \mathrm{~min}$ & $75-1350 \mathrm{~min}$ \\
\hline Small Pelvic areas & 10 & 13 \\
\hline Heifers (No.) & $130 \mathrm{~min}$ & $381 \mathrm{~min}$ \\
\hline Average & $30-330 \mathrm{~min}$ & $30-900 \mathrm{~min}$ \\
\hline Range &
\end{tabular}

Table 7. Effect of Clenbuterol to delay second stage of parturition in heifers

\begin{tabular}{|c|c|c|}
\hline & Control & Clenbuterol \\
\hline Large Pelvic areas \\
\hline Heifers (No.) & 10 & 13 \\
\hline Average & 86 minute & 107 minute \\
\hline Range & $20-150$ minute & $15-145$ minute \\
\hline Small Pelvic areas & 10 & 13 \\
\hline Heifers (No.) & 120 minute & 54 minute \\
\hline Average & $45-270$ minute & $5-240$ minute \\
\hline Range
\end{tabular}

Clenbuterol treatment can delay the second stage of parturition for 107 minutes in heifers with large pelvic areas, whereas the same treatment can delay the same stage for only 54 minutes (Table 7). The exact reason for this variation in the delay time of parturition was not known so further it is a part of research for the future researchers.

Clenbuterol $300 \mu \mathrm{g}, \mathrm{i} / \mathrm{m}$ can be used to postpone the parturition at different stages in cows $(\mathrm{n}=100)$ and found that during Clenbuterol treatment, the duration of tocolysis depends on the position of the fetus at the time of treatment, being longest at the beginning of the labor process (Stage-I). The average interval from clenbuterol injection to calving at the time of 2 fingers cervical dilation, 4 fingers cervical dilation, full hand cervical dilation and second stage of parturition was 23.4 hours, 14.2 hours, 9.9 hours and 5.2 hours, respectively.

Apart from bovine species, tocolysis can be achieved in ovine and porcine also. Various researchers from different countries had reported such examples. Clenbuterol, $240 \mu \mathrm{g}$, i/m, abolished uterine motoricity for 8-10 hrs in sheep, suspending overnight lambing in $91 \%$ of ewes subjected to trial. Clenbuterol treatment in ewes effectively resulted in to delayed parturition for at least $10 \mathrm{hr}$. in most ewes. Nifedipine $80 \mu \mathrm{g} / \mathrm{kg}$, i/v treated in sheep resulted into delayed parturition for 6-7 hours. Hirst et al (2005) used Clenbuterol, $6 \mathrm{ml}$, i/m in ewes to delay lambing for 7 hours. In porcine species tocolytic drugs can be used for two purposes. As pigs are the polytocus animals these drugs can be used for Interruption of parturition and also for the postponement of farrowing during night hours.

\section{Reduction in neonatal morbidity and mortality in dystocia}

In dystocia affected animals there are every chance of neonatal morbidity and/or mortality. So to overcome this burning problem it is advisable to use tocolytic drugs in such cases as it is reported that tocolytic drugs can relax the uterine smooth musculature. In dystocia affected animal there is violent straining is observed in order to expulse the fetus. After some time the animal may become exhausteddue to energy loss. The fetal fluid is drained out of the womb and the uterus becomes dry. In many cases obstetrical assistance can overcome this problem but inthe extensive exhaustion and dry uterus condition, there is difficulty in manual relieve of dystocia. In 
such cases tocolytic drugs become helpful as they have a very good smooth muscle relaxant and analgesic action.

The use of tocolytic drugs proved advantageous in dystocia affected animals as it require less amount of epidural anaesthesia, easy and correct diagnosis of obstetrical defects can be achieved, low incidence of retained placenta, Facilitate obstetrical maneuvers i.e. repositioning of head and neck deviations, corrections of malpresentations and malpostures, repulsion and rotation of fetus, correction of forelimb retention and hock flexion and breech presentation (Menard, 1994) and Low incidence of genital prolapse. A very good plane of uterine relaxation was observed in cows affected with dystocia treated with $5 \mathrm{mg} / \mathrm{kg}$, i/v, terbutaline (Melanie et al., 2007).

\section{Obstetrical operations, cesarean section and fetotomy}

The success of cesarean section mainly depends upon avoidance of intra-peritoneal infection and efficient suturing of the incised uterine wound. Due to extensive fetal movement and muscular stretching the infected uterine fluid may enter the peritoneal cavity and subsequently resulted into peritonitis. Due to extensive muscular contraction uterine exteriorization cannot be facilitated, that may hinder the suturing of the uterine wound. Therefore it is recommended to use tocolytic drug in the cases of cesarean section.

Clenbuterol $(300 \mu \mathrm{g}, \mathrm{i} / \mathrm{m})$ administered in cows undergoing cesarean section resulted in to easy extraperitoneal lifting of the uterus, no risk of anaesthetic induced decumbency and Impermeable closure of uterine muscles (DeNooij, 1984), low incidence of retension of placenta (DeNooij, 1984 and Menard and Diaz, 1987), prevention of post-operative adhesions (Menard and Diaz, 1987) and reduced mortality of dam and calf (Menard and Diaz, 1987). Ahlers and Anderson (1967) studied the effect of Isoxsuprine in 66 cows undergoing cesarean section. $10 \mathrm{ml}$ Isoxsuprine when administered intramuscularly in cows, 10 minutes before cesarean section, it resulted in to exteriorization of the uterus in $90 \%$ cases undergoing trial.Reports of the use of tocolytic drug in sheep and pig are also available. Menard and Diaz(1987) illustrated a very good uterine relaxation, improved ease of manipulationand exteriorization of uterus during caesarean section performed in sheep $(n=3)$ using Clenbuterol at a dose tare of $0.8 \mu \mathrm{g} / \mathrm{kg}$ body weight.In a Berkshire saw also a cesarean section was performed with the use of 6 $\mathrm{ml}$ Isoxsuprine, $\mathrm{i} / \mathrm{m}$, and a good uterine relaxation was noticed and uterus could be easily exteriorized.

Dystocia cases which cannot be relieved manually undergo fetotomy and then finally attempted for the cesarean section. Preferably fetotomy is often choosing for relieving dystocias over cesarean section. Fetotomy is performed due to various fetal (fetal oversize, fetal monsterocity, hydrocephalus, fetal anasarca, emphysema, mummification, maceration etc.) and maternal (small pelvis, incomplete cervical dilation, pelvic fracture, abnormal pelvis etc.) causes. Various cuts are applied over the fetal body i.e. head, neck, forelimb, hind limb and abdominal and thoracic region in order to reduce the fetal body size according to presentation, position and posture of the fetus lying in the womb of the dam. In such cases there is violent muscular contraction is noticed.It is a prime factor to reduce the uterine muscular contraction at the time of fetotomy to achieve best results during obstetrical maneuver.Tocolytic drugs can play a very good role in such cases. During fetal postural defects Isoxsuprine and Clenbuterol (DeNooij, 1984) in cows at the dose rates of $10 \mathrm{ml}, \mathrm{i} / \mathrm{m}$ and $300 \mu \mathrm{g}, \mathrm{i} / \mathrm{m}$, respectively and Clenbuterol in cases of equine (DeNooij, 1984) and cow (Menard and Diaz, 1987) at the dose rate of $75 \mu \mathrm{g}, \mathrm{i} / \mathrm{m}$ and $300 \mu \mathrm{g}, \mathrm{i} / \mathrm{m}$, respectively caused a very good uterine relaxation.. During Fetal Emphysema Isoxsuprine in cows at the dose rate of $10 \mathrm{ml}, \mathrm{i} / \mathrm{m}$ resulted in to a very good uterine relaxation and fetotomy was performed easily.

\section{Uterine prolapse}

Prolapse of the uterus may occur in any species; however, it is most common in dairy and beef cows and ewes and less frequent in sows. (It is rare in mares, bitches, queens, and rabbits.) The etiology is unclear and occurrence is sporadic. Recumbancy with the hindquarters lower than the forequarters, invagination of the tip of the uterus, excessive traction to relieve dystocia or retained fetal membranes, uterine atony, hypocalcemia, and lack of exercise have all been incriminated as contributory causes. Prolapse of the uterus invariably occurs immediately after or within several hours of parturition, when the cervix is open and the uterus lacks tone. Prolapse of the postgravid uterine horn usually is complete in cows, and the mass of uterus usually hangs below the hocks. The invagination of the contralateral horn can be located by careful examination of the surface of the prolapsed organ. In sows, one horn may become everted while unborn piglets in the other prevent further prolapse. In small animals, complete prolapse of both uterine horns is usual. Uterine prolapses occur at or shortly after calving. Many times they occur with a difficult birth. The uterus is literally pulled through the birth canal with the calf or the afterbirth and again exposed to the weather elements, potential injury, and certainly infectious agents. In such cases the use of the tocolytic drugs proved to be advantageous. Clenbuterol (DeNooij, 1984) in cows treated at a dose of $3 \mathrm{mg}, \mathrm{i} / \mathrm{m}$, and Isoxsuprine at a dose of $10 \mathrm{ml}, \mathrm{i} / \mathrm{m}$ resulted in to the onset of action waswithin 15 minutes of administration and reposition was easily facilitated without reoccurrence. In sheep (Zennetti, 1983) also Isoxsuprine and Clenbuterolat a dose of $10 \mathrm{ml}, \mathrm{i} / \mathrm{m}$ and $0.001 \mathrm{mg} / \mathrm{kg}, \mathrm{i} / \mathrm{m}$, respectively resulted in to onset of action was within 15 minutes of administration and reposition was easily facilitated without reoccurrence.

\section{Uterine torsion}

Uterine torsion is more common in the cow than any other domestic species. The etiopathogenesis of the condition remains open to speculation. Uterine torsion in the cow is usually associated with advanced pregnancy 
and parturition but has been reported to occur as early as $70 \mathrm{~d}$ of gestation (Roberts, 1986). It is predisposed to by the relatively unstable suspension of the bovine uterus, a relatively empty rumen increasing space in the abdominal cavity, the manner in which cows get up and lie down, and sudden stumbles and falls. Factors that probably contributed to uterine torsion in this cow were an unstable uterus resulting from a small or nonfunctional nongravid horn, lack of fetal fluids, and a large abdomen (Menard, 1994).

Menard, 1994 used Clenbuterol at a dose of $0.3 \mathrm{mg}$, i/min cows affected with uterine torsion. They found the onset of tocolysis within 15-20 minutes and tremendous result was achieved in the form of good uterine relaxation and successful detorsion without affecting the vitality of the dam and newborn.

\section{Embryo biotechnology}

The practice of bovine embryo transfer (ET) is an ever changing science that involves three major events. It begins with selection, superovulation, and artificial insemination (A.I.) of the donor animal. Next, the embryos are recovered from the donor through either surgical or nonsurgical means, evaluated, and then frozen or transferred fresh. Lastly, the recipient animals are synchronized to be in the same stage of the estrous cycle as the donor when the embryo was recovered and receive the embryos through surgical or nonsurgical techniques. During the process of estrus synchronization in the recipient animal prostaglandin treatment is generally given. Under the effect of prostaglandin the uterine smooth musculature becomes contracted and straining is observed at some extent. The tocolytic drugs have a muscular relaxant effect on gravid as well as non-gravid uterine horn. So, application of tocolysis can be proved best effective in embryo biotechnologyas far as the embryo transfer is concerned.

Gregory and Rodrigues, 1986 conducted a trial for comparison of effectiveness of various tocolytic drugs like Planipart (Clenbuterol: 0.3mg), Duvadilan (Isoxsuprine: $20 \mathrm{mg}$ ) and Aerolin (Salbutamol: $4.8 \mathrm{mg}$ ) and found that the pregnancy rates were $38 \%, 48 \%$ and $46 \%$, respectively.

\section{Conclusions}

Among the $B$-sympathomimetic drugs used in animal reproduction, only clenbuteroland isoxsuprinehave been used widely in clinical management of obstetrical disorders apart from embryo biotechnology with encouraging post therapeutic results.

The efficacy of tocolytic drugs is mostly assessed clinically and pharmacokinetic of each need to be studied in detail to ensure wide use with awareness of adverse effects of drug metabolites, if any.

\section{References}

1) Ahlers D. and Anderson U. (1967).Experiences with the uterine relaxant isoxsuprine lactate in cases of difficult labor in cows. Dtsch Tierarztl Wochenschr, 74 (23): 608-610.

2) Dave M., Sauer M.J. and Fallon R.J. (1998). Clenbuterol plasma pharmacokinetics in cattle.The Analyst, 123: 2697-2699.

3) DeNooij P.P. (1984). The use of Clenbuterol for Obstetrical procedures in forty cows and one horse.Canadian Veterinary Journal, 25: 357-359.

4) Erkert R.S. and Macallister C.G. (2002). Isoxsuprinehydrochloride in the horse: a review. Journal of Veterinary Pharmacology and Therapeutics, 25: 81-7.

5) Garg S.K., Garg K.M. and Sabir M. (2004).Evaluation of tocolytic efficacy of selective beta2 adrenoreceptor agonists on buffalo uterus.Indian Journal of Experimental Biology, 42: 913-918.

6) Gregory R.M. and Rodrigues J.L. (1986). Pregnancy rates after Embryo Transfer using drugs that produce relaxation of the uterus. Theriogenology, 25 (1): 157.

7) Hirst J.J., Parkington H.C.,Young I.R., Palliser H.K., Peri K.G. and Olson D.M. (2005).American Journal of Obstetrics and Gynecology, 193: 256-66.

8) Innes I.R. and Nicherson, M. (1975).Norepinephrine, epinephrine and the sympathomimetic amines.In: Goodman, L.S. and Gilman, A. (eds.), The pharmacological bases of therapeutics. $5^{\text {th }}$ ed.: MacMillan Publishing Co. Inc., New York, 478.

9) Kiguchi S., Matsuda T., Cho K., Okuyama K., Akahane M., and Fujimoto S. (2002). KUR-1246, a Novel $\beta 2-$ Adrenoceptor Agonist, as a Tocolytic Agent .Obstetrics and Gynecology, 100 (3): 487-494.

10) Matsuda Y., Kouno S., Sakamoto H. and Ikenoue T. (2002). Effects of Meluadrine Tartrate and Ritodrine Hydrochloride on Oxytocin-induced uterine contractions, uterine arterial blood flow and maternal cardiovascular function in pregnant goats.Japanese Journal of Pharmacology, 90: 107-113.

11) Melanie J.B., Washburn K.E., Clarke C.R., Streeter R.N. and Maxwell L.K. (2007). Terbutaline pharmacokinetics in cows: preliminary data. The Canadian Journal of Veterinary Research, 71:70-73.

12) Menard L. and Diaz C.S. (1987). The use of clenbuterol for the management of large animal dystocias: Surgical corrections in the cow and ewe. Canadian Veterinary Journal, 28 (9): 585-590.

13) Menard L. (1994). The use of clenbuterol in large animal obstetrics: Manual correction of bovine dystocias. Canadian Veterinary Journal, 35: 289-292. 
14) Mohamed M.Y., Abd El-Hakeam A.A,. Abd El-Salam O.M 2021. Effect of Oxytocin on uterine involution, cervical dilation and resumption of ovarian activity post-lambing in Ossimi ewes. Journal of Livestock Science 12:161-169.

15) Norwitz E.R., Robinson J.N. and Challis J.R.G. (1999).The New England Journal of Medicine 341 (9): 660666.

16) Perez R., Garcia M., Arias P., Gallardo M. and Valenzuela M. (1997). Inhibition of xylazine induced uterine contractility by Clenbuterol and Nifedipine. Research in Veterinary Science, 63:73-76.

17) Putnam, M.R., L.E. Rice, R.P. Wettemann, K.S. Lusby, and B. Pratt. 1985. Clenbuterol (PlanipartTM) for the postponement of parturition in cattle. Theriogenology. 24: 385-393.

18) Roberts S.J. (1986).Veterinary Obstetrics and Genital Diseases, Theriogenology, 3rd ed. Woodstock Vermont Publishers. 19: 213-217, 230-233, 337-343.

19) Zennetti G. (1983). Clinical aspects of the use of the $\beta 2$ mimetic 'clenbuterol' in treatment of prolapse in ewe. Veterinary Bulletin, 53 (11) Ab: 1064. 